\title{
KAZÁN JELLEGGÖRBE ELEMZÉSE HŐKEZELÉSI FOLYAMAT OPTIMALIZÁLÁSÁHOZ
}

\author{
Dr. Ph.D. Fabulya Zoltán \\ adjunktus, Szegedi Tudományegyetem Mérnőki Kar, Szeged
}

\begin{abstract}
SUMMARY
The quality and rentability of preserved food (besides the quality of the basic materials, the good recipe, the features of the production belts) are determined by their heat-treatment and its organization. The production process which was not planned carefully can imply quality problems and considerable increase of expenses. To support work organization with computer has not been in practice in Hungary so far. My main objective in case of technologies with an autoclave group is to elaborate a program system based on simulation which could help reduce the direct costs of heattreatment and improve the quality of products. For this objective it is necessary to carry out further sub-tasks and examinations whose results should be utilized in the system. One of these is to analyse with simulation the load-dependent efficiency graph of gas boiler which provides the necessary amount of steam and then to use the results to find the conditions of optimal operation and to calculate costs reduction arising from it.
\end{abstract}

\section{BEVEZETÉS}

A konzervek hökezelése, különösen húskonzervek esetén nagy energiaigényü folyamat, mivel sterilezéssel, $120^{\circ} \mathrm{C}$ körüli, hosszú időtartamú hőhatással jár (Szenes és Oláh, 1991; Deák, 2006; Kovács, 1997). Mindeközben a természeti erőforrások felhasználásának csökkentése is fontos szempontként jelenik meg. Ez, a korábban energiatakarékosságnak nevezett tevékenység ma már kibövül a környezet menedzsment új rendszerszemléletével, a fenntartható fejlödés elvével, azaz kevesebb energiafelhasználással termelni ugyanannyi terméket, vagy több terméket elöállítani fajlagosan kevesebb energiafelhasználás mellett (Kerekes és Szlávik, 1996). Bár ezeknek (pl. viz, elektromos és hőenergia) a felhasználásoknak a csökkentése nyilvánvaló költségcsökkentést, gazdaságosság javulást eredményez, nehéz keresztülvinni a megvalósitást az üzemekben, mert az elszámolás pótlékolva, átlagosan történik. Nem tesznek különbséget a valós felhasználás alapján, így a pazarlások, túlzott mértékü felhasználások nem mutathatók ki egyértelmüen, mint ahogy a minöségi javulás és a beltartalmi érték növekedése sem.

A termékek minősége és a költséghatékony termelés érdekében mérnöki számításokat, modellezést, számítógépes szimulációt érdemes bevonni a témakör kutatásába. Olyan munkaszervezést kell kialakítani, mely garantálja a mikrobiológiai szempontból biztonságos termék elöállítását, az elöírások pontosabb betarthatóságát a magasabb minőség és alacsonyabb költségek érdekében. Ehhez szükséges olyan informatikai háttér, mely a kutatási eredmények alapján támogatást nyújt a megfelelő munkaszervezés kialakításában. Mindez a kor igényeinek megfelelő felhasználóbarát kezelőfelületekkel, szimulációs optimalizáló technikával, elörejelző, problémafeltáró szolgáltatásokkal biztosítható, egyúttal rugalmas bővítési lehetöségekkel tehetö meg.

Hipotézisem szerint az időben változatlan értékủ kazánterhelés biztosítja az elérhető maximális átlagos hatásfokot, míg a nagyobb ingadozású, szórású terhelések alacsonyabb átlagos hatásfokot eredményeznek ugyanakkora átlagos terhelés mellett, vagyis ugyanakkora mennyiségü termék hökezelése során. 


\section{ANYAG ÉS MÓDSZER}

A vizsgálathoz szükséges jelleggörbe kritikus, intenzívebb hatásfok változását mutató szakaszát ábrázoló diagram (1. ábra) az adatokat biztosító vállalat kazánjának dokumentációjában állt rendelkezésre azzal a szöveges kiegészítéssel, hogy $50 \%$ terhelés felett is folyamatosan nő a hatásfok, és $100 \%$ terhelésnél éri el a $90 \%$-ot. Szintén e dokumentáció tartalmazta, hogy ez a jelleggörbe általánosságban minden hagyományos kazánra érvényes. Az ábra függöleges tengelyén a hatásfok azt fejezi ki, hogy a kazán fütésére felhasznált gázmennyiségből kalkulálható hỏmennyiség hány százaléka jelenik meg a kazánból kilépő gőz hőenergiájában. $\mathrm{Ez}$ azt jelenti, hogy a hökezeléshez szükséges mennyiségü höenergiát alacsonyabb hatásfok esetén nagyobb mennyiségü fütőgáz tudja csak fedezni. Tehát a maximális hatásfok elérésére kell törekedni, ami a kazán adott terhelése, vagyis a hökezelendő termék mennyisége mellett elérhető. Az ábra vízszintes tengelyén a kazán terhelése százalékban azt fejezi ki, hogy az idöegység alatt maximálisan biztosítható, göz formájában kilépö hömennyiség hány százalékával terheljük a kazánt.

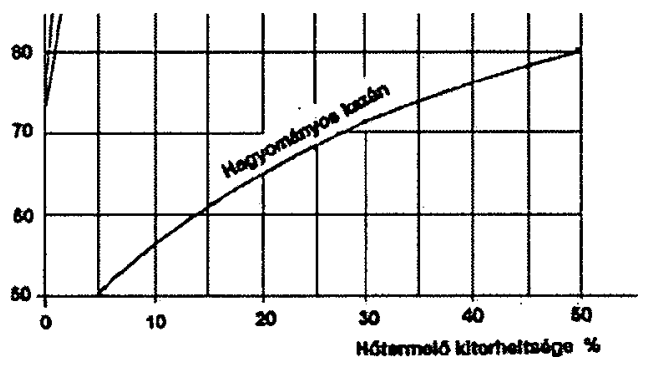

1. ábra. Kazán hatásfoka a terhelés függvényében Forrás: kazán dokumentációja

A kutatás során függvényillesztésre volt szükség, vagyis paraméterektől függő számítógépes model thez megtalálni a paramétereknek azt az értékkombinációját, amikor a modellel adódó eredmények minél pontosabb közelitését adják az ismert, megfigyelt adatoknak. Ehhez az Excel táblázatkezelö program Solver bővítményét alkalmaztam a legkisebb négyzetek módszerével. Ennek technikája, hogy egy-egy cellában megadjuk a keresett paramétereknek egy lehetséges kezdőértékét, valamint kialakítunk egy olyan számolótáblát, mely a paraméterek megváltozásakor automatikusan képzi egy cellában az összetartozó számított (szimulált) és ismert értékpárok különbségeinek négyzetösszegét. Ezután a Solver müködtetéséhez beállítjuk, hogy melyek a keresett paraméterek cellái, mint módosuló cellák és a négyzetösszeg cellája, mint minimalizálandó érték. A Solverrel a megoldást kérve megkapjuk a paraméterek keresett értékkombinációját. Erre volt szükség az 1. ábrán látható jelleggörbe matematikai függvénnyel leírásához is.

Különbözö eloszlású kazánterhelés adatokat szimuláltam véletlenszám-generálással (Monte Carlo módszer), hogy a modellel adódó eredmények alapján elemezhessem az egyenetlen kazánterhelés hatását a költségekre. Természetesen ez nagyon drága kísérletsorozat lett volna (amire lehetöségem sem lett volna), ha nem modellezéssel végzem. A Monte Carlo módszer lényege, hogy a mért adatok (kazánterhelések) helyett azok szimulált (véletlenszámként generált) értékeit alkalmazzuk a számítógépes modell bemenetén, $s$ az így kapott eredményeket értékeljük ki a mért hatás (hatásfok alapján meghatározott gázfelhasználás) helyett. 


\section{EREDMÉNY ÉS ÉRTÉKELÉS}

Ahhoz, hogy adott terheléshez automatikusan megkaphassuk a hatásfokot, szükségünk volt a jelleggörbét leíró matematikai formájú függvényre. Tehát egy olyan függvényt kerestem, mely a $[0,1]$ intervallum értékeihez (ami a [0\%, 100\%] terheléstartomány megfelelője,) hozzárendeli a grafikonon látható hatásfok értékeket. A görbe jellegéhez illeszkedő 0 és 1 közötti kitevőjü $\mathrm{f}(\mathrm{x})=\mathrm{x}^{\mathrm{n}}$ hatványfüggvényt választottam. A függvény lefelé eltolására (transzformációjára) is szükség volt (kb. 10\%-kal), így a pontos érték megtalálása érdekében ezt is paraméternek tekintettem. Tehát a terhelés és a hatásfok kapcsolatát leíró függvényt a következő formában kerestem:

$$
y=f(x)=x^{n}-d,
$$

ahol:

- $\mathrm{x}$ - terhelés,

- $\mathrm{y}$-hatásfok,

- $\mathrm{n}, \mathrm{d}$ - keresett paraméterek.

A paraméterek értékét az Excel program Solver bővítményével kerestem meg a legkisebb négyzetek módszerét alkalmazva. Ehhez a jelleggörbéről leolvastam adott terhelésekhez ( $10 \%$-os lépésenként) a hatáfok értékeket, $\mathrm{s}$ az ettől legkisebb mértékủ eltérést eredményező paramétereket kaptam. Így a következỏ függvény adódott:

$$
y=f(x)=x^{0.2}-0,09 \text {. }
$$

$\mathrm{Az}$ ismert hatásfok adatokból képzett grafikon és a modelljéül szolgáló függvény ábrázolása mutatta (2. ábra), hogy a két adatsor statisztikai egyezőségének vizsgálatára már nincs szükség. Az ábrán szaggatott vonallal a kazán jelleggörbéjérỏl leolvasott pontokon áthaladó görbe látható, míg a másik, a keresett függvénnyel adódott értékeken alapul.

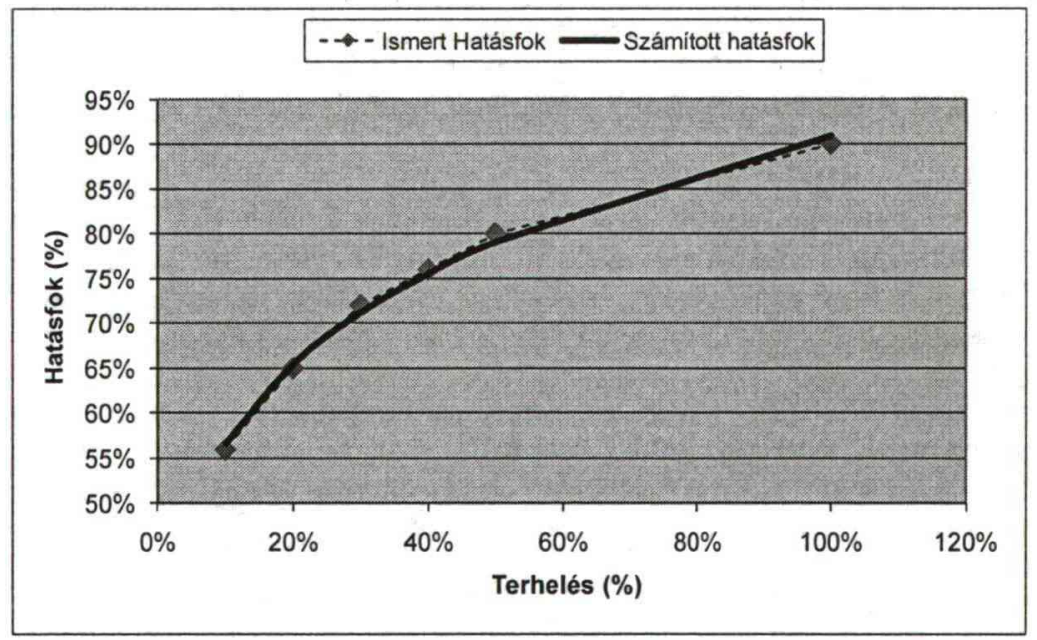

2. ábra. Ismert és számított hatásfokgörbék a terhelés függvényében Forrás: a szerző saját szerkesztése

A függvény segítségével már tetszőleges értékü terheléshez megkapható a hatásfok.

Az elemzés során arra kerestem a választ, hogy adott átlagértékü, de különböző szórású, eloszlású kazánterhelések, milyen átlagértékü hatásfokot eredményeznek (1. táblázat). Így 
megkapható, hogy adott termékmennyiség (kazánterhelés) hőkezelése mekkora hatásfokkal, ebböl következően gázfelhasználással biztosítható a terhelés egyenletességétől függően. A hatásfok relatív vesztesége azt mutatja, hogy az adott átlagos terhelés mellett maximálisan elérhetö hatásfokhoz viszonyitva, mekkora veszteség jelenik meg százalékban. A terhelés eloszlása azt az értéktartományt jelenti, melyben mozog a kazán terhelése.

1. táblázat. Kazán hatásfokának elemzése különböző terhelések mellett

\begin{tabular}{|c|c|c|c|c|}
\hline \multirow{2}{*}{$\begin{array}{c}\text { Átlagos } \\
\text { terhelés }\end{array}$} & $\begin{array}{c}\text { Terhelés } \\
\text { eloszlása }\end{array}$ & $\begin{array}{c}\text { Átlagos } \\
\text { hatásfok }\end{array}$ & $\begin{array}{c}\text { Hatásfok } \\
\text { relatív } \\
\text { vesztesége }\end{array}$ & $\begin{array}{c}\text { Költségnövekedés } \\
100 \text { millió Ft-os éves } \\
\text { gázdij esetén }\end{array}$ \\
\hline \multirow{3}{*}{$70 \%$} & $70 \%-70 \%$ & $84,11 \%$ & $0,0 \%$ & 0 \\
\cline { 2 - 5 } & $65 \%-75 \%$ & $84,06 \%$ & $0,1 \%$ & $100 \mathrm{eFt}$ \\
\cline { 2 - 5 } & $40 \%-100 \%$ & $82,66 \%$ & $1,8 \%$ & $1800 \mathrm{eFt}$ \\
\hline \multirow{3}{*}{$50 \%$} & $50 \%-50 \%$ & $78,06 \%$ & $0,0 \%$ & 0 \\
\cline { 2 - 5 } & $30 \%-70 \%$ & $75,83 \%$ & $2,9 \%$ & $2900 \mathrm{eFt}$ \\
\cline { 2 - 5 } & $20 \%-80 \%$ & $75,39 \%$ & $3,5 \%$ & $3500 \mathrm{eFt}$ \\
\cline { 2 - 5 } & $10 \%-90 \%$ & $74,39 \%$ & $4,9 \%$ & $4900 \mathrm{eFt}$ \\
\hline \multirow{2}{*}{$30 \%$} & $30 \%-30 \%$ & $69,60 \%$ & $0,0 \%$ & 0 \\
\cline { 2 - 5 } & $10 \%-50 \%$ & $65,58 \%$ & $6,1 \%$ & $6100 \mathrm{eFt}$ \\
\hline
\end{tabular}

A kazánterhelések százalékos adatának generálásához a gyakorlatban lehetséges átlagértékeket és közelítő eloszlásukat vettem figyelembe. A kazán terhelésének éves átlaga $50 \%$ körüli. Egyenetlen terhelés egyik fő indoka a szezonalitás, amikor az egyes termékek igen nagy eltéréssel igényelnek hökezelést. Természetesen ekkor nincs mód a terhelés kiegyensúlyozására. Egy másik, kutatásom szempontjából lényegesebb eset, amikor egyszerre többfajta, eltérö terheléssel járó terméket készitenek, $s$ a gyártás mủszakokra bontása során ezt nem veszik figyelembe, mint ahogy a jelenlegi gyakorlatban is ezt tapasztaltam. Ekkor például a müszakonkénti 50\%-os átlagos terhelés helyett jellemzö, hogy az egymást követő müszakokban akár 30\%-os és $70 \%$-os átlagterhelés jelentkezik. Viszont egy müszakon belül is nagy eltérések adódhatnak, amikor a párhuzamosan, több autoklávban zajló hökezeléseket nem hangolják össze.

Mindebböl látható, hogy a terhelések eloszlása nagyon széles skálán mozoghat, de például normális eloszlásúnak biztosan nem tekinthetö. Emiatt a terhelés kiegyensúlyozatlanságára jellemző, különbözö értékhatárok közötti egyenletes eloszlású adatsort generáltam. Meghatároztam az így adódó hatásfokok átlagát és a relativ eltérést a kiegyensúlyozott állapothoz képest. $\mathrm{E}$ relatív vesztesége a hatásfoknak egyúttal a kazán gázfelhasználásának vesztesége.

A vizsgálat során 30,50 és $70 \%$ átlagos terhelések mindegyikénél megvizsgáltam, hogy a szórás milyen mértékben befolyásolja a hatásfokot. Az 1. táblázat utolsó oszlopában látható, hogy az adott átlagterhelés mellett mekkora relatív eltérése adódik a hatásfoknak, s így a költségnek a maximálisan elérhetö, szórás nélküli esettől.

\section{KÖVETKEZTETÉSEK}

$\mathrm{Az}$ eredményekböl látható, hogy a terhelés kiegyensúlyozatlanságának növekedésével a veszteség is emelkedik. Kisebb átlagterhelések mellett nagyobb jelentösége van a terhelés kiegyenlítésének, hiszen ekkor $6 \%$ is lehet a relatív veszteség. Az éves átlagnak tekinthetö $50 \%$-os terhelés mellett a legrosszabb esetben csaknem $5 \%$ veszteség adódott, ami például 100 millió Ft éves gázdij esetén 5 millió Ft költségnövekedést jelent. 


\section{IRODALOMJEGYZÉK}

Deák, T. (2006): Élelmiszer-mikrobiológia. Mezögazda Kiadó, Budapest, p. 48., 138.

Kerekes, S., Szlávik, J. (1996): A környezeti menedzsment közgazdasági eszközei. Környezetvédelmi kiskönyvtár 2. Közgazdasági és Jogi Könyvkiadó, Budapest, pp. 37-38.

Kovács, Á. (1997): Az élelmiszertudomány alapjai Ill. Élelmiszerek mikrobiológiája és mikroökológiája. (Jegyzet.) Pécsi Orvostudományi Egyetem Egészségügyi Főiskolai Kar, Pécs, p. 148., 199., 327.

Szenes, E., Oláh, M. (szerk.) (1991): Konzervipari kézikönyv. Integra-Projekt Kft., Budapest, pp. 67-70. 